\title{
Integrated marketing communication model for creating brand loyalty to Japanese cars in Thailand
}

\author{
Sudaporn Sawmong \\ Faculty of Business and Administration
}

King Mongkut's Institute of Technology, Ladkrabang, Bangkok, Thailand

\section{Keywords}

Integrated marketing communication model, Brand loyalty, Japanese cars, Thailand

\begin{abstract}
Thailand automobile market has experienced growth for several years due to worldwide economic growth. The proposed policies present great opportunities for Japanese car companies who have such technologies and willing to invest in an emerging markets region. This research aimed to find the integrated marketing communication model for creating brand loyalty to Japanese cars in Thailand. The quantitative data was collected via questionnaire survey to 460 Japanese car customers in Thailand. The sampling method used the simple random sampling at the department of Land Transport, Bangkok, Thailand. The descriptive statistics applied in this research consist of mean average, percentage and frequency, whereas inferential statistics consisted of confirmatory factor analysis, path analysis and Structural Equation Modeling. The study found that the integrated marketing communication model for creating brand loyalty to Japanese cars in Thailand consisted of car factors, customer psychological factors, integrated marketing communication tools, and brand loyalty. The constructed model developed by this research is consistent with the empirical data and showed the ability to predict value perception to an acceptable degree with a multiple correlation's squares $\left(R^{2}\right)$ of $87 \%$, GFI $=0.96, A G F I=0.93$, Chi-Square $=114.91, D F=94, P$-Value $=0.089$, and $R M S E A=$ 0.022. These finding were achieved through better understanding and addressing the Japanese car producer on integrated marketing communication model for creating brand loyalty in Thailand. The practical implication model has been suggested in this paper
\end{abstract}

Corresponding author: Sudaporn Sawmong

Email addresses for corresponding author: sudaporn.sa@kmitl.ac.th

First submission received: $10^{\text {th }}$ June 2018

Revised submission received: $7^{\text {th }}$ September 2018

Accepted: 21 $1^{\text {st }}$ September 2018

\section{Introduction}

Thailand automobile industry is one of the key major players in the industrial sector in ASEAN country and contributes heavily to the nation's economy. In 2017, Thailand automotive industry was the largest in Southeast Asia and the 12 th largest in the world. Most of the vehicles built in Thailand are developed and licensed by producers, mainly Japanese, Europe and American (Thai Automotive industry Association, 2017). The Industry employs more than 300,000 people and generator on average percent of the national gross domestic product (GDP) and create a number of service and support out fits, plastic to steel making, repair and maintenance and engine software design accounting for approximately $11 \%$ of the Thai GDP (Ernst \& and Young, 2017 and Wikipedia 2018). In 2017, the automobile industry shares a large part of the country's export in come with annual capacity of 1.8 million units of which half is the destined for export (Ministry of Commerce Thailand, 2017), while the total import value of automobile and related parts accounted for $3 \%$ of the total national import value of 156,990 million baht $(\$ 4,757)$ (Ministry of Commerce Thailand MOC, 2017). Table 1 shows the passenger car by unit's sales market share and growth of passenger car by units in 2017. 


\begin{tabular}{|c|c|c|}
\hline Maker/Brand & Growth (units) 2017 & $\mathbf{2 0 1 7}$ \\
\hline Toyota & 239,551 & $30.0 \%$ \\
\hline Isuzu & 160,550 & $14.8 \%$ \\
\hline Honda & 127,768 & $13.9 \%$ \\
\hline Mitsubishi & 69,737 & $8.5 \%$ \\
\hline Nissan & 59,709 & $6.7 \%$ \\
\hline Ford & 56,156 & $6.5 \%$ \\
\hline Mazda & 51,355 & $6.0 \%$ \\
\hline Suzuki & 25,011 & $3.0 \%$ \\
\hline Chevrolet & 18,771 & $2.7 \%$ \\
\hline Mercedes Benz & 14,324 & $1.7 \%$ \\
\hline Others & 48,712 & $6.2 \%$ \\
\hline total & 871,644 & $100 \%$ \\
\hline
\end{tabular}

Table1 Passenger Car unit sold Thailand by Maker/Brand and Growth year 2017 and Market Share (Ministry of Commerce Thailand, 2017)

The sales figures in Table 1 clearly show the domination of Japanese Car manufacturers in Thailand's passenger car market. The information indicated that the top five brand passenger car maker were Japanese cars followed by European and other Asian automobile companies in Thailand in 2017. The figure clearly identifies that automobile factories from Japan can utilize their production capacities much better than the others. The top five car brands Toyota, Isuzu, Honda, Mitsubishi, and Nissan have already attained brand reputation and customer' base in Thailand. Thus, the five brands are the main significance for this study because of the success in creating brand loyalty for Japanese Cars.

Kotler \& Keller (2016) and Shiffman \& Kanuk, (2015) stated that the element to classify those products or services of the cooperate to the brand loyalty are product factors, customer's psychological factors and integrated marketing communication tool, this study will be focused on brand loyalty to the car business in Thailand.

This research aims to find the integrated marketing communication model for creating brand loyalty to Japanese cars in Thailand by answering the following questions. What are the components of the car factors, Thai customer's psychological factor and integrated marketing communication tools, and the brand loyalty of Japanese cars in Thailand? Do the car factors, Thai customer's psychological factors and the integrated marketing communication tools have any effects on the brand loyalty of Japanese cars in Thailand. Finally what is the effective integrated marketing communication model to create brand loyalty for Japanese car brands in Thailand.

\section{Objectives of the Research}

The objective of the research is to find the integrated marketing communication model for creating brand loyalty to Japanese cars in Thailand.

\section{Contributions to the Research}

This research aims to investigate the integrated marketing communication tools that will enable the Japanese car business in Thailand to improve their brand loyalty. The major contributions of this research Japanese car investors as well as attracting the new investors to invest in Thailand. Customers of Japanese cars will benefit from the research due to the improvement of the brand loyalty building programs of the Japanese car companies which will lead to optimum customer satisfaction. The finding will also be beneficial to researchers and the public as they can use the research results as a guideline for future research.

\section{Literature Review and research Conceptual Framework}

This research has utilized the theory and previous research that are relevant to the variables of car factors. The variables consist of car factors (country of origin, quality, price, and brand reputation), psychological factors (motivation, attitude, and personality), the integrated marketing communication (IMC) tools (public relations, sponsorship, advertising, direct marketing, sales promotion, exhibitions, personal selling, and customer relationship management (CRM), and brand loyalty (satisfaction, image, repeat purchase, and word-of-mouth) as following. 
Shiffman \& Kanuk, (2015) define consumer behaviour as the behaviour that consumers display in searching for, purchasing, using, evaluating, and disposing of products, services, and ideas. While Kotler \& Keller (2016) said that the successful marketers are those who carefully cultivate satisfaction and loyalty. Hence consumer purchases are influenced strongly by psychological characteristics of motivation, personality and attitude (Kotler and Armstrong, 2016). The important question of marketers is how consumers respond to various marketing efforts the company might use, for example, the IMC tool including public relations, sponsorship, advertising, direct marketing, sales promotion, exhibitions, personal selling, and CRM. The company that really understands how consumers will respond to different quality of products, country of origin, prices, and brand reputation has a great advantage over its competitors (Belch, 2004). This can be extended to create the customer relationship management (CRM) and build brand loyalty from the brand image satisfaction customer repeat purchase and, finally, the customer will action word of mouth; as Kotler \& Keller (2016) stated that the successful marketers are who carefully cultivate satisfaction and loyalty.

The previous research into CRM strategies in relation to the motor industry suggested that (Sophie 2014) CRM strategies in enhancing customer loyalty in the motor industry in Zimbabwe. The motor industry is facing intense competition both locally and internationally. The paper analyses trust and commitment as antecedents of customer loyalty, the benefits of database marketing and key account management, categories of loyalty, as well as challenges affecting the effective implementation of database marketing and key account management. The research design was descriptive and exploratory. A sample size of 297 respondents was used. The major finding was that trust and commitment have a role to play as they led to customer loyalty. It was therefore concluded that CRM contributes significantly towards customer loyalty in the motor industry, thus it was recommended that the motor industry could make optimum use of information technology in order to fully implement CRM strategies.

The previous research into Dimensions of Service Quality Models (Emeil 2014). The objective is to measuring service quality and service quality dimensions. This study focused on the service quality models. The methodology of this study was to review the existing service quality models in chronologic order. The dimensions of the models were examined and three main groups that consist of service quality dimensions were obtained. They were associated with the three elements of services marketing mix (7P) such as product price place promotion people process and physical environment. It was advised that practitioners should pay attention the services marketing tools and $7 \mathrm{P}$ to increase the quality of their services offered.

The previous research into The National Safety Council (NSC), Albert (2015) studied on estimated that over 35,000 people died in U.S. traffic accidents. About 3.8 million traffic crash injuries requiring medical attention occurred in2013, and the number of deaths was about the same over the last 5 years. The NSC found that product recalls, car repairs, injuries, and deaths were due to unsafe product designs or inferior product quality. These statistics underscore the challenge of producing quality vehicles while satisfying customers. Data was collected from a random sample $(N=77)$ of U.S. automobile users and analysed via simple and multiple linear regression, which showed a significant statistical relationship between product quality and customer satisfaction. However, neither the product safety nor product cost helped mediate the relationship between product quality and customer satisfaction. Building high-quality cars leads to fewer injuries and deaths associated with vehicular accidents, thus promoting positive social change for both U.S. automobile buyers and sellers.

The previous research into the analysis of archetypal characteristics of socialcustomer relationship management Social Customer Relationship Management (SCRM) Karol and June (2015) is a relatively new concept in contemporary marketing studies. Although its general understanding seems to be rather intuitive and simple within business managerial environments, as the sole name of it induces the usage of social media (SM) and data that it contains and constantly produces in company's CRM strategies, scholars still struggle to create its holistic definition or even one unified description and a general list of characteristics. In this paper, we discuss and find deficiencies and incoherencies among researched works and detecting a group of characteristics archetypal to contemporary SCRM.

Recently research into an empirical approach to consumer buying behaviour in Indian automobile sector Prateek, Nitin and Anoop (2017). The study purpose of this paper is to understand the relationship 
between advertisement effectiveness and consumer buying behaviour for major automobile companies of central India. Research design has adopted a judicious mix of qualitative data by focus group and Delphi technique and quantitative data used structured questionnaire survey. Research findings found that for the automobile sector, effective advertisements have a positive impact on consumer buying behaviour. It suggests that customer's attitude can be shaped favourably through effective advertising. Automobile companies must arrange special training sessions and learning programs for their sales force to ensure supportive customer purchasing behaviour.

Recently research into the effect of corporate brand reputation on brand attachment and brand loyalty: automobile sector (Loureiro, Sarmento, \& Bellego 2017). The study aims to analyse the effect of corporate brand reputation on brand attachment and brand loyalty considering the automotive sector and the brands Tesla, Toyota, and Volvo in Portugal. A sample of 327 participants, members of car brand communities, collaborates in a survey. Overall findings reveal that the perception of corporate brand reputation is more effective on enhancing brand loyalty than brand attachment. However, the effect could depend on the car brand strategy. The researcher claimed that customer citizen helping others is one of the most important corporate attributes perceived by customers of the three brands

Recently research into a mediated model of relationship quality factors affecting behavioural intention at a luxury motor vehicle dealership (Estelle 2017). The aim of this study is to determine whether customer satisfaction, trust and commitment as relationship quality factors can be valuable to a luxury motor vehicle dealership in generating favourable behavioural intentions concerning post-purchase service and repair offerings. A descriptive research design was followed, and self-administered questionnaires were fielded among customers of the luxury motor vehicle dealership. A total of 301 questionnaires were returned and the interrelationships between the constructs were examined using structural equation modelling. Research findings found that, it was discovered that customers who trust the dealership may be more committed, and commitment may strengthen the relationship between customer satisfaction and a favourable behavioural intention towards the dealership.

An exploration of the previous research related to Integrated Marketing Communication Model for Creating Brand Loyalty to Japanese Cars in Thailand. An information can be classified into 3 dimensions for creating brand loyalty which were car factors, psychological factor, IMC tool factor from Belch (2004), Emil (2014), Sophie (2014) Albert (2015), Karol, Hoffman \& Karuk (2015), Karol \& June (2015), Kotler \& Armstrong, (2016), Kotler \& Keller (2016), Pratik, Nitin \& Snoop (2017), Estelle (2017), Lourier Sarmento \& Bellego (2017) and the related theories; such as, consumer behaviour theory, attitude theory, and concepts; including integrated marketing communication concept, customer relationship management concept, brand loyalty concept, quality concept, country of origin effect concept, price concept, brand concept and previous researches, specifically for brand loyalty, car factors, psychological factors, integrated marketing communication tools, the research conceptual framework has been constructed as displayed in Figure 1 


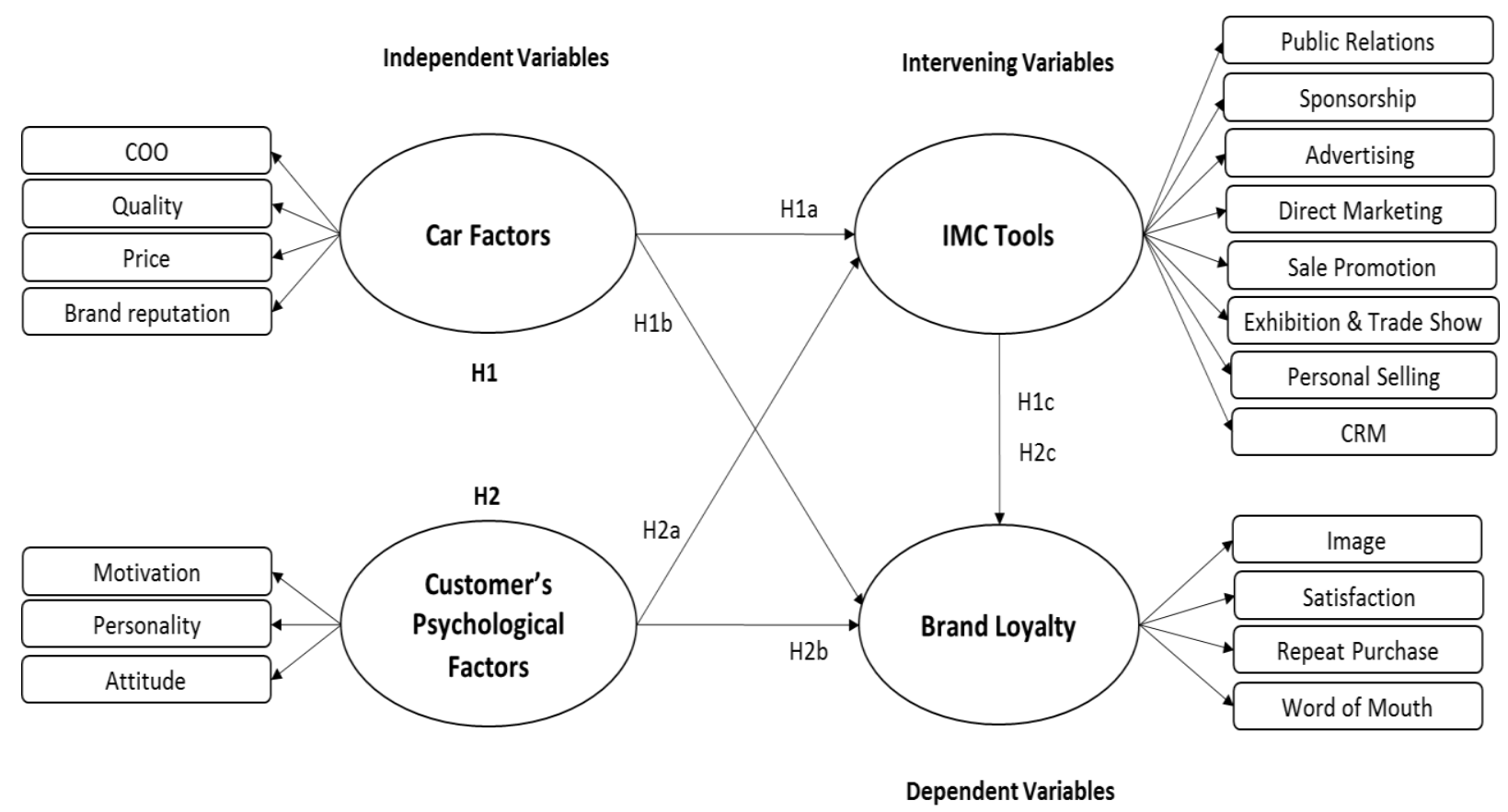

Figure 1 Research conceptual framework entitles "Integrated Marketing

Communication Model for Creating Brand Loyalty to Japanese Cars in Thailand"

\section{The Components of Variables}

This research is the study of the casual effect among 4 latent variables, two of them are independent variables, and the rest are intervening and dependent variables. As identified in Figure 1, the independent variables consist of car factors; country of origin, quality, price, and brand reputation. Psychological factors are; motivation, attitude, and personality. The intervening variable is the integrated marketing communication tools of public relations, sponsorship, advertising, direct marketing, sales promotion, exhibitions, personal selling, and CRM. The dependent variable is brand loyalty of satisfaction, image, repeat purchase, and word-of-mouth.

Research Hypotheses

Regarding the literature from many resources in the marketing field such as Belch (2004), Hoffman \& Karuk, (2015), Karol \& June (2015), Kotler \& Armstrong (2016), Kotler \& Keller (2016), Flourier et al (2017), Estelle (2017) and Pratik \& Snoop (2017), these theories, concepts and findings are very relevant and supported this research hypothesis. The two main research hypotheses were set up from the integrated of their findings as follow.

Research hypothesis one (H1): There are direct and indirect effects between car factors, integrated marketing communication tools, and brand loyalty. This hypothesis supported by Belch (2004), Emeil (2014), Siphiwe (2014), Albert (2015), Karol \& June (2015), Estelle (2017) and Prateek, Nitin \& Anoop (2017).

$\mathrm{H}_{1 \mathrm{a}}$ : There are direct effects between car factors and integrated marketing communication tools. $\mathrm{H} 1_{\mathrm{b}}$ : There are direct effects between car factors and brand loyalty.

$\mathrm{H} 1_{\mathrm{C}}$ : There are indirect effects between car factors and brand loyalty through integrated marketing communication tools.

Research hypothesis two (H2): There are direct and indirect effects between customer's psychological factors, integrated marketing communication tools, and brand loyalty. This hypothesis supported by Emeil (2014), Siphiwe (2014), Karol \& June (2015) Shiffman \& Kanuk, (2015), Kotler \& Keller (2016), Kotler \& Armstrong (2016), Loureiro et al (2017) and Prateek, Nitin \& Anoop (2017).

$\mathrm{H} 2_{\mathrm{a}}$ : There are direct effects between customer's psychological factors and integrated marketing communication tools. 
$\mathrm{H}_{2 b}$ : There are direct effects between customer's psychological factors and brand loyalty.

$\mathrm{H} 2_{\mathrm{c}}$ : There are indirect effects between customer's psychological factors and brand loyalty through integrated marketing communication tool

\section{Research Design}

The research design in the study use quantitative research methodology, the detail of procedures necessary for obtaining information needed for the research are outlined as population, sample, sampling method, research tool, data collection, as well as statistical and data analysis outlined below Quantitative Research

The objective of the quantitative research was to analyse the variables appropriate for generating loyalty and to find the effective integrated marketing communication model affecting the loyalty of Thai consumers to Japanese cars in Thailand. The previous chapter introduced the literature related to all latent and observed variables. In this section, the population and sample, sampling method, research tools and the process of questionnaire construction, data collection, data collection, and data analysis method are explained.

\section{Population and Sample}

According to the Department of Land Transport, more than $70 \%$ of Japanese car sales are in Bangkok, the survey was undertaken in Bangkok. The population in this study has focusing on the group of car buyers of top five Japanese brands; Toyota, Isuzu, Honda, Mitsubishi, and Nissan in the year 2017 which were 657,315 car owners (Table 2). These five brands have obtained the total passenger car unit sold in 2017 as shown in Table 1, in previous section. The purpose for selecting the year above was because the car buyers have had experiences with the current integrated marketing communication tools, loyalty building campaign, and latest products. The sample was calculated by proportion to size, to meet the minimum requirement for the use of structural equation modeling (SEM), in this research which was 20 times of the study variables. The sums of observed and latent variables were 23; then the sample size must have at least 460 samples, as showed in Table2 (Hair, Black, Babin and Anderson 2010).

\begin{tabular}{|l|l|l|}
\hline Brand & Population & Sample \\
\hline Toyota & 239,551 & 168 \\
\hline Isuzu & 160,550 & 112 \\
\hline Honda & 127,768 & 89 \\
\hline Mitsubishi & 69,737 & 49 \\
\hline Nissan & 59,709 & 42 \\
\hline Total & 657,315 & 460 \\
\hline & & \\
\hline
\end{tabular}

Table 2 Population and Simple of Japanese Passenger car Owners in 2017 Research Tools

The questionnaire design consisted of 68 questions, which were divided into five parts commencing with personal factors, and consequently followed by car factors, customer' psychological factors, IMC tools, and brand loyalty. The testing of validity was undertaken by an Item Objective Congruence (IOC) by three academician experts or determining the content validity, which every item have validity more than 0.66 .

The questionnaire was sent to a test sampling of 30 participants of similar homogeneity to the selected population. A Cronbach Alpha Coefficient has been tested to determine the overall reliability of 0.95 in this study.

\section{Data Collection}

The data collection was conducted during the period of January 2018- April 2018 at the department of Land Transport, Bangkok, Thailand. The Systematic simple random sampling was applied for the data collection. The sampling was done brand by brand with same method while the owners of the car drive through the line for car checking in every 5 cars. The questionnaire was handed and collected each case within 40 minutes. The researcher provided one bottle of drinking water to the respondents. 


\section{Statistical and Data Analysis}

The research was analysed by the descriptive statistics consists of mean average, percentage and frequency, whereas inferential statistics consisted of confirmatory factor analysis, path analysis and structural equation modeling.

Conclusion and Discussion

The Discussion and conclusion have been divided in to three parts: 1) results of the factor loading of car factors, customer's psychological factors, integrated marketing communication tools, and brand loyalty 2) Hypotheses testing results and 3) the results of the integrated marketing communication model for creating brand loyalty to Japanese cars in Thailand.

Part1: Results of the factor loading of car factors, customer's psychological factors, integrated marketing communication tools, and brand loyalty

This section displays the Model for Creating Brand Loyalty to Japanese Cars in Thailand, the factor loading values ranging from the most important 10 the least important factor in regards with the method of completely standardized solution of the model of the Integrated Marketing Communication Model for Creating Brand Loyalty to Japanese Cars in Thailand reordering by factor loading showed in figure2.

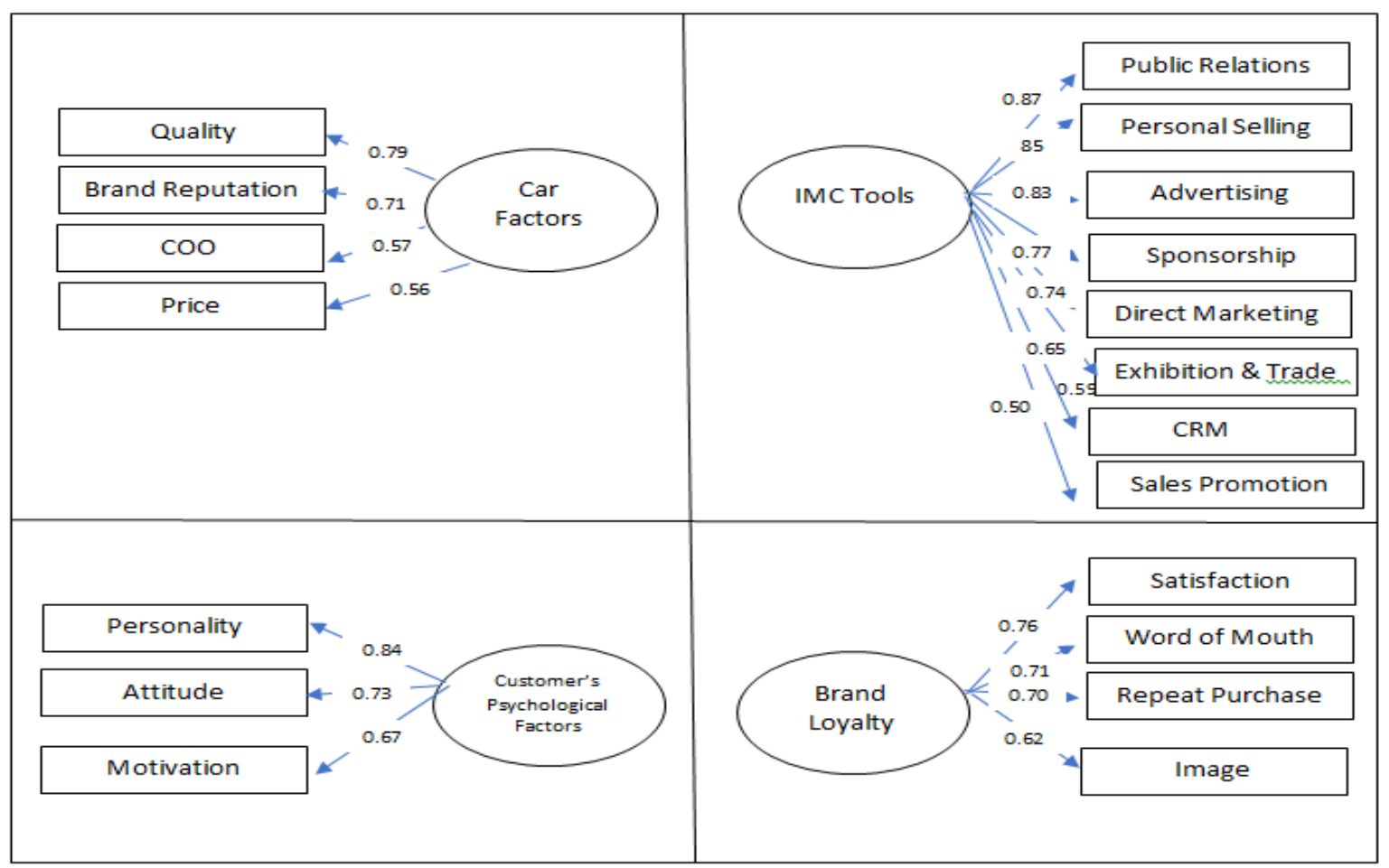

Figure 2 Factors Loading Estimated Value of Integrated Marketing Communication Model for Creating Brand Loyalty to Japanese Cars in Thailand. (Sawmong, 2018)

In car factors, highest factor loading is quality with the value of 0.79 , follow by brand reputation with 0.71 , country of origin 0.57 and price with 0.56 respectively.

In the customer's psychological factors Personality has the highest factor loading in with the value of 0.84 , follow by attitude with 0.73 , and motivation with 0.67 respectively. The new ranking order from most important variable to the least important is personality, attitude and motivation.

Integrated marketing communication tools; public relations have the highest factor loading value of 0.87 , follow by personal selling with 0.85 , advertising with 0.83 , sponsorships with 0.77 , direct marketing with 0.74 , exhibition and trade show with 0.65 , customer relationship management with 0.55 , and sales promotion with 0.50 respectively. The new ranking order from most important variable to the least important is public relations, personal selling, advertising, sponsorships, direct marketing, exhibition and trade show, customer relationship management, and sales promotion. 
In the brand loyalty, the highest factor loading value is satisfaction with the value of 0.76 , follow by word of mouth with 0.71 , repeat purchase with 0.70 , and image with 0.62 respectively. The new ranking order from most important variable to the least important is satisfaction, word of mouth, repeat purchase and image.

The values of factor loadings for all variables in "Integrated Marketing Communication Model for Creating Brand Loyalty to Japanese Cars in Thailand " in completely standardized solution method shows the statistical value ranking in order of importance of all' variables concerned in the constructed model in relation to each other. The new ranking in order is illustrated in Figure 2

Part2: Hypotheses testing results

This section indicates the analysis of the directions of the direct and indirect effects among the latent variables of car factors, customer's psychological factors, integrated marketing communication tools, and brand loyalty, the conclusion of the hypotheses testing is showed in Table 3 and Table 4

\begin{tabular}{|l|l|l|l|l|l|}
\hline Variables & TE & IMC \\
(IMCTOL) & LOYALTY \\
(BRALOY)
\end{tabular}

Table 3 Results of the Path Analysis

The conclusion, of the hypotheses testing of the research "Integrated Marketing Communication Model for Creating Brand Loyalty to Japanese Cars in Thailand", was that car factors have direct positive effect on integrated marketing communication tools as well as brand loyalty and have indirect positive effects on brand loyalty through integrated marketing communication tools. Customer's psychological factors do not have direct effects on integrated marketing communication tools do not have indirect effects on brand loyalty through integrated marketing communication tools; however, there are direct positive effects on brand loyalty. The conclusion of the hypotheses testing is showed in Table 4 . 


\begin{tabular}{|c|c|c|}
\hline Hypotheses & supported & rejected \\
\hline $\begin{array}{l}\text { 1. Research hypothesis one (H1): There are direct and } \\
\text { indirect effects between car factors, integrated marketing } \\
\text { communication tools, and brand loyalty }\end{array}$ & & \\
\hline $\begin{array}{l}1.1 \text { Hla: There are direct effects between car factors and } \\
\text { integrated marketing communication tools }\end{array}$ & $\checkmark$ & \\
\hline $\begin{array}{l}1.2 \text { Hib: There are direct effects between car factors and } \\
\text { brand loyalty }\end{array}$ & $\checkmark$ & \\
\hline $\begin{array}{l}\text { 1.3 Hlc: There are indirect effects between customer car } \\
\text { factors and brand loyalty through integrated } 1 / \text { marketing } \\
\text { communication tools }\end{array}$ & $\checkmark$ & \\
\hline $\begin{array}{l}\text { 2. Research hypothesis two (H2): There are direct and } \\
\text { indirect effects between customer"s psychological factors, } \\
\text { integrated marketing communication tools, and brand } \\
\text { loyalty }\end{array}$ & & \\
\hline $\begin{array}{l}2.1 \text { H2a: There are no direct effects between customer's } \\
\text { psychological factors and integrated marketing } \\
\text { communication tools }\end{array}$ & & $\checkmark$ \\
\hline $\begin{array}{l}2.2 \mathrm{H} 2 \mathrm{~b}: \text { There are direct effects between customer's } \\
\text { psychological factors and brand loyalty }\end{array}$ & $\checkmark$ & \\
\hline $\begin{array}{l}2.3 \mathrm{H} 2 \mathrm{c} \text { : There are no indirect effects between customer's } \\
\text { psychological factors and brand loyalty through } \\
\text { integrated marketing communication tools }\end{array}$ & & $\checkmark$ \\
\hline
\end{tabular}

Table 4 Conclusion of the hypotheses testing

Car factors and Integrated Marketing Communication Tools

The path coefficient shows that there are direct positive effects (DE) between car factors and integrated marketing communication tools with the value of 0.53 at the significance level of 0.01 The result implies that when car factors are increased, integrated marketing communication tools should be implemented to convey the attributes of the car, quality of the brand, reputation of the brand to a greater number of potential consumers. Quality concept suggested that loyalty can be created if a consumer is satisfied with the product or service-received. Satisfaction occurs when the product or service performed their function well in the mind of the consumers by meeting or exceeding their expectation. This notion is supported by the studies of Belch (2004), Emeil (2014), Siphiwe (2014), Albert (2015), Karol \& June (2015), Estelle (2017) and Prateek, Nitin \& Anoop (2017).

\section{Car Factors and Brand Loyalty}

The path coefficient demonstrated that there are direct positive effects (DE) between car factors and brand loyalty of Japanese cars with the value of 0.54 at the significance level of 0.11 The result implies that when car factors increase, the level of the brand loyalty to Japanese car's brand will develop positive attitude toward the brand if the consumer is satisfied with the quality of the product or service as well as the image they received. The motivating the consumer to refer the brand to others and repurchase the brand in the future. The notion is supported by the studies of Belch (2004) Albert (2015), Kotler \& Keller (2016), Kotler \& Armstrong (2016), Estelle (2017) and Loureiro (2017))

\section{Car Factors, Brand Loyalty, and Integrated Marketing Communication Tools}

The path coefficient shows that there are indirect positive effects (IE) between car factors and brand loyalty through integrated marketing communication tools with the value of 0.11 at the significance level of 0.01 between the tested variables. This implies that the communication on car factors through integrated marketing communication tools will result in the increase in level of brand loyalty.

The research result is supported by the studies of Estell 2017 and Loureiro (2017)) and Kotler \& Keller (2016), Kotler \& Armstrong (2016) that the decision to buy an automobile comes from the active information from direct and indirect sources; such as, company's own advertising or social network. The information received will create the preference towards a brand and magnify the willingness to purchase from the brand, if it happens to be on the same track and answers the needs of the potential prospects. 


\section{Customer's Psychological Factors and Integrated Marketing Communication Tools}

This research shows that there are no direct effects (DE) between customer's psychological factors and integrated marketing communication tools. The finding is in line with Emel (2014), Siphiwe (2014), Karol \& June (2015) Shiffman \& Kanuk, (2015), Kotler \& Keller (2016), Kotler \& Armstrong (2016), Loureiro (2017) and Prateek, Nitin \& Anoop (2017). Those researchers found the major customer's psychological factors enticing purchases did not come from marketing communications from the car companies. Customers are motivated to buy because of the urge to express their life achievement through materialism, and the Japanese cars brand images can answer their needs. The prestigious images of Japanese brands are learnt since childhood and through peer pressure in the high societies, rather than from marketing communications. Personalities are not relevant to purchases decision, utilitarian customer often purchases Japanese car to fit himself into his social norms

\section{Customer's Psychological Factors and Brand Loyalty}

The path coefficient shows that there are direct positive effects (DE) between customer's psychological factors and brand loyalty with the value of 0.32 at the significance level of 0.01 . The result suggests that when the customer's psychological factors increase, the level of brand loyalty will also be increased. This finding is concurrent to consumer behavior theory of Schiffman \& Kanuk (2010) stated that in general a buyer prefers to buy a brand that matches his/her personality. A customer is motivated to become an advocate of a car's brand, if he/she develops favourable attitude about the brand after having satisfactory experiences. This finding also supports Kotler \& Keller (2016), Kotler \& Armstrong (2016) as they stated that image, satisfaction, repeat purchase and word of mouth are linked to brand loyalty

\section{Customer's Psychological Factors Integrated Marketing Communication Tools and Brand Loyalty}

The path coefficient shows that there are indirect effects (IE) between customer's psychological factors IMC tool and brand loyalty with the value of 0.17 at the significance level of 0.11 . Between the tested variables this finding contrasts with Shiffman \& Kanuk, (2015), who identified that consumer behaviour as the behaviour that consumers display in searching for, purchasing, using, evaluating, and disposing of products, services, and ideas. Kotler \& Keller (2016) said that the successful marketers are who carefully cultivate satisfaction and loyalty. Hence consumer purchases are influenced strongly by psychology characteristics motivation personality and attitude (Kotler \& Armstrong, 2016). The important question of marketers is how consumers respond to various marketing efforts the company might use IMC tool such as public relations, sponsorship, advertising, direct marketing, sales promotion, exhibitions, personal selling, and CRM. This may be because consumer behaviour in the aftermath of 2000 has something to do and marketers should find out why that is.

\section{Part3: Results of the Integrated Marketing Communication Model for Creating Brand Loyalty to Japanese Cars in Thailand}

This part showed the result of the analysis of Goodness of Fit for the Integrated Marketing Communication Model for Creating Brand Loyalty to Japanese cars in Thailand. The initial scales resulted in a Chi-Square of 114.91, degrees of freedom of 94, Chi-Square $/ \mathrm{df}=1.222, \mathrm{P}=0.009$, a Goodness of Fit Index (GFI) of 0.98, Adjusted Goodness of Fit Index (AGFI) of 0.95, and Root Mean Square Residual (RMR) of 0.037 indicating a good fit of model. The Root Mean Square Error of Approximation (RMSEA) of 0.020 and Critical N (CN) of 532.16 also support this conclusion. A Goodness of Fit Index (GFI) represents the overall degree of fit that predicted by the proposed model ranging in value from 0 (poor fit) to 10 (perfect fit). Higher values indicate better fit. The Adjusted Goodness of F it Index (AGFI) is an extension of the GFI that recommends the acceptance level at the value greater than or equal to 0.90 (Hair, Black, Babin \& Anderson 2010). Initial scales for proposed model provide AGF I of 0.95 that is higher than the recommended acceptance level of 0.90 . This statistic shows support that the results of this study fit to the proposed model. Table 5 shows all the relevant statistical measurement values indicating that the constructed model fit to the empirical factual data.

According to the analysis of the model which consists of four latent variables of car factors, customer's psychological factors, integrated marketing communication tools, and brand loyalty display 
results as follows: Car factors consist of four observed variables: country of origin has a factor loading of 0.57; quality has a factor loading of 0.79; price has a factor loading of 0.56 ; and brand reputation has a factor loading of 0.71 at the significance level 0.01 . The results indicate that country of origin; quality, price, and brand reputation have positive relationships with car factors in the same direction. Customer's psychological factors consist of three observed variables: personality has a factor loading of 0.84 attitude has a factor loading of 0.73 motivation has a factor loading of 0.67 and at the significance level 0.01 . The results indicate that personality, attitude and motivation have positive relationships with the customer's psychological factors in the same direction. Integrated marketing communication tools consist of eight observed variables: public relations, personal selling, advertising, sponsorships, direct marketing, exhibition and trade show, CRM, and sale promotion has a factor loading of $0.87,0.85,0.83,0.77,0.74$, $0.65,0.59$, and 0.50 respectively at the significance level 0.01 . The results indicate that public relations, sponsorships, advertising, direct marketing, sales promotions, exhibition and trade show, personal selling, and customer relationship management have positive relationships with integrated marketing communication tools in the same direction

Brand loyalty consists of four observed variables: satisfaction, word of mouth, repeat purchase and image has factor loading $0.76,0.71,0.70$, and 0.62 respectively at the significance level 0.01 . The results indicate that, the factor loading estimated value shows the direct and indirect effect value of all variables and hypothesis testing of each latent variable which will test how the empirical data fit with the constructed model.

\begin{tabular}{|c|c|c|c|c|}
\hline $\begin{array}{l}\text { Goodness of Fit } \\
\text { measure }\end{array}$ & $\begin{array}{l}\text { Acceptable } \\
\text { Level }\end{array}$ & Reference & Statistic & Conclusion \\
\hline Chi-Square & & & 114.91 & \\
\hline df & $\mathrm{P}>0.05$ & Carmines and Mclver & 94 & Accepted \\
\hline P-Value & $\begin{array}{l}\text { Chi- } \\
\text { Square/df }\end{array}$ & (1981) & 0.089 & Accepted \\
\hline CMIN/df & $<3$ & & 1.187 & \\
\hline $\begin{array}{l}\text { Goodness of } \\
\text { (GFI) }\end{array}$ & GFI $>0.90$ & Hu and Bender (1999); & 0.98 & Accepted \\
\hline $\begin{array}{l}\text { Adjusted Goodness } \\
\text { of } F \text { it (AGFI) }\end{array}$ & $\begin{array}{l}\text { AGFI close to } \\
0.90\end{array}$ & Hair, et a1. (2006) & 0.95 & Accepted \\
\hline $\begin{array}{l}\text { Root Mean Square } \\
\text { Residual (RMR) }\end{array}$ & RMR $<0.08$ & $\begin{array}{l}\text { Schmackerand Lomax } \\
\text { (1996) }\end{array}$ & 0.015 & Accepted \\
\hline $\begin{array}{l}\text { Root Mean Square } \\
\text { Error of } \\
\text { Approximation } \\
\text { (RMSEA) }\end{array}$ & RMSEA $<0.50$ & Hair, et a1. (2006) & 0.020 & Accepted \\
\hline Critical N (CN) & $\mathrm{CN}>200$ & $\begin{array}{l}\text { Diamantopoulos and } \\
\text { Siguaw (2000) }\end{array}$ & 531.15 & Accepted \\
\hline
\end{tabular}

Table 5 the relevant statistical measurement values indicating that the constructed model fit to the empirical factual data

The analysis of the model reveals that car factors have direct positive effects with integrated marketing communication tools (0.53) as well as brand loyalty (0.54) and have indirect positive effects with the brand loyalty through integrated marketing communication tools (0.17). The analysis arrives at the conclusion that the higher level of car factors and integrated marketing communication tools will result in higher level of brand loyalty. The analysis of the model states that customer's psychological factors do not have direct effects with integrated marketing communication tools and do not have indirect effect with brand loyalty through integrated marketing communication tools but have direct and positive effects with brand loyalty. The analysis arrives to the conclusion that the higher level of customer's psychological factors will result in higher level of brand only as shown in Factor Loading Estimated Value of Integrated Marketing Communication Model for Creating Brand Loyalty to Japanese Cars in Thailand in Figure 3. 


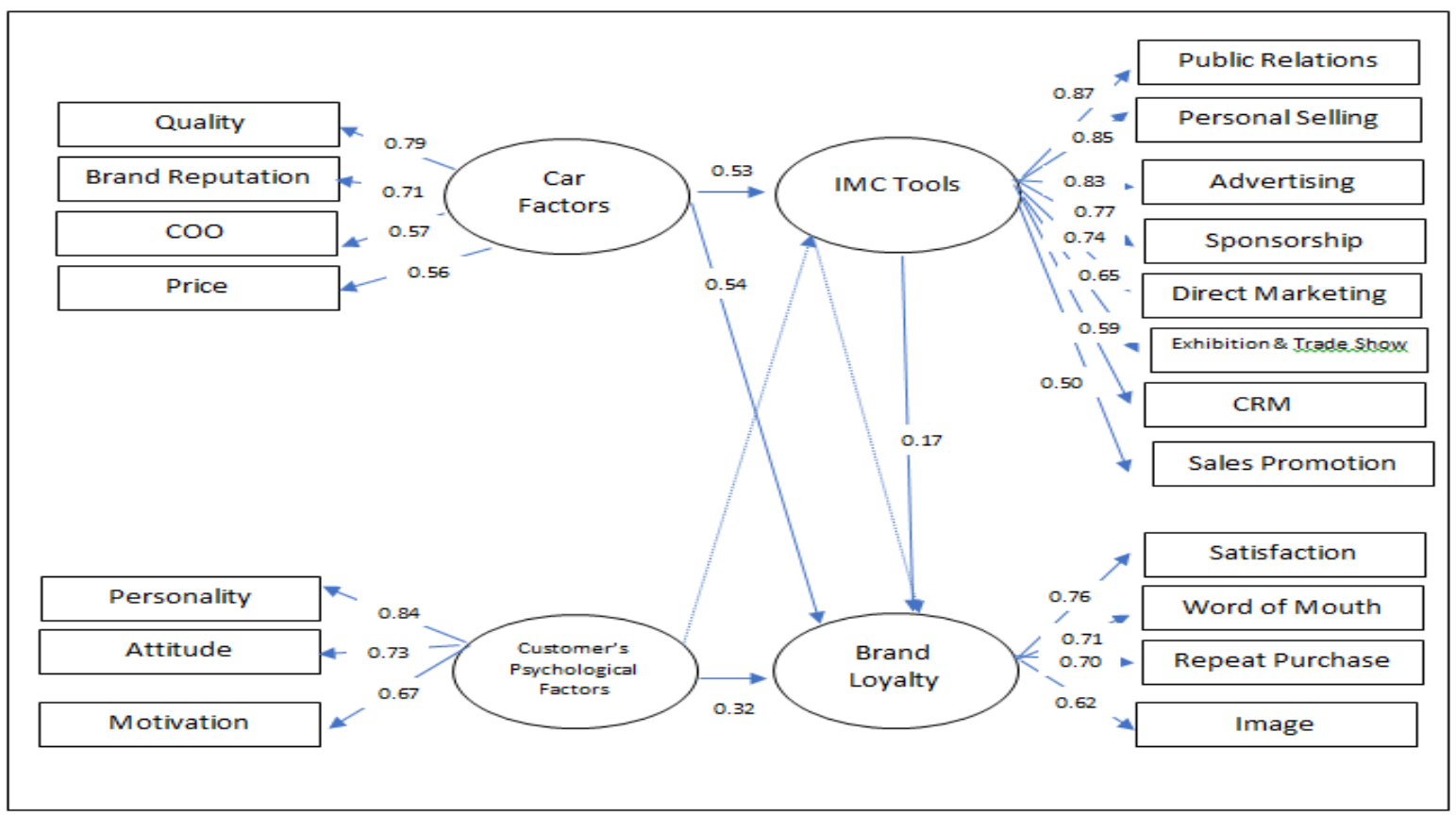

Figure 3 Integrated Marketing Communication Model for Creating Brand Loyalty to Japanese Cars in Thailand (Sawmong, 2018)

\section{Conclusion}

The important result of Integrated Marketing Communication Model for Creating Brand Loyalty to Japanese Cars in Thailand found that car factors have direct and indirect effects on integrated marketing communication tools, and brand loyalty. This integrated marketing communication programs have been concurrent with Schiffman \& Kanuk (2015) Kotler \& Keller (2016) definition of consumer behaviour as the behaviour that consumers display in searching for, purchasing, using, evaluating, and disposing of products, services, and ideas. The important question of marketers is how consumers respond to various marketing efforts the company might use IMC tool such as public relations, sponsorship, advertising, direct marketing, sales promotion, exhibitions, personal selling, and CRM. The company that really understands how consumers will respond to different quality of product, country of origin, prices, and brand reputation has a great advantage over its competitors (Belch, 2004). In relation to brand loyalty in dimension of image satisfaction repeat purchase and word of mouth, the findings are concurrent with Estelle (2017) that the strength of the car factors are linked to brand loyalty. Automobile corporations operate in an industry that possesses substantial profit potentials and each customer is worth more than only the sales price for a car. The Integrated Marketing Communication Tools (IMC) is one of the best arsenals that have been proven to be effective in creating customer loyalty. Each tool may serve different strategic purposes which together resulting in establishing and enhancing brand loyalty. On the other hand, the finding found that there are no direct effects between customer's psychological factors and integrated marketing communication tools $(\mathrm{H} 2 \mathrm{a})$ and there are no indirect effects between customer's psychological factors and brand loyalty through integrated marketing communication tools (H2c). The findings from this research show Thai customer psychology pays low attention to IMC Tools. The meaning of this situation can explain that Japanese companies must work harder to create strategy to be actively involved with motivation, personality and attitude of Thai customer by setting many activities as stated by Kotler and Armstrong, (2016) and research finding of Siphiwe (2014), Emeil (2014), Albert (2015), Karol \& June (2015), Loureiro et al (2017), Estelle (2017) and Prateek, Nitin \& Anoop (2017).

Research limitations and direction further research

In order to extend the understanding of consumer behaviour, a qualitative research to Japanese car customers concerning integrated marketing communication tools that will affect their psychological factors resulting in enhancing their brand loyalty is recommended. 
The comparison study on government policy concerning import tax rate with new emerging Asian countries are recommended because it has direct association with the cost structure and pricing policy of the company. People in the country that have low car import tax rate are free to choose and enjoy the quality of the car than the one in the country that have high import tax rate. This is one of the barriers for creating brand loyalty in high-ended car market.

\section{References}

Albert, V. C, (2015) Relationship between Product Quality and Customer Satisfaction in the U.S. Automobile Industry. Doctoral dissertation, College of Management and Technology, Walden University

Belch, G. E, (2004) Advertising and Promotion: An Integrated Marketing Communications Perspective. McGraw-Hill/Irwin. Department of Land Transport, (2017) Statistic of Japanese car sales in Thailand.

Emil, K. Y, (2014) A Review on Dimensions of Service Quality Models. Journal of Marketing Management. June 2014, Vol. 2, No. 2, pp. 79-93

Estelle, V, T . (2017) A mediated model of relationship quality factors affecting behavioural intention at a luxury motor vehicle dealership. European Business Review. Vol. 29 No. 1, 2017 pp. 43-60. Emeralds Publishing Limited 0955-534X. [Online] DOI 10.1108/EBR-08-2016-0113. Available from

https://www.emeraldinsight.com/doi/full/10.1108/EBR-08-2016-0113?fullSc=1 [Accessed 18 May. 2018].

Ernst \& and Young. (2017) Automotive market in Thailand: Industry overview Building a better working world. [Online] Available from http://www.ey.com/gl/en/newsroom/news-releases/ey-newsroom-news-releases2017. [Accessed 19 April. 2018].

Hair, J.F., Black, W.C., Babin, B.J. \& Anderson, R.E. (2010). Multivariate Data Analysis (7th ed). New Jersey: Pearson Prentice Hall

Kotler, P \& Armstrong, G. (2016) Principle of Marketing (16th ed). New Jersey: Pearson Education.

Ministry of Commerce Thailand. (2017) Passenger Car unit sold Thailand by Maker/Brand and Growth year 2017 and Market Share.

Karol J, and June-S, C. (2015) Analysis of archetypal characteristics of socialcustomer relationship management. Journal of Business and Retail Management Research (JBRMR) Vol. 9 Issue 2. Pp. 85-99. [Online] Available from http://jbrmr.com/admin/content/pdf/i-18_c-161.pdf [Accessed 19 April. 2018].

Kotler, P \& Armstrong, G. (2016) Principles of Marketing (16th Global Edition). Pearson Education Limited

Kotler, P \& Keller, K.L. (2016) Marketing Management (15th Global Edition). Pearson Education Limited

Loureiro, S, M, C, Sarmento, M, E., and Bellego, G, L (2017) the effect of corporate brand reputation on brand attachment and brand loyalty: Automobile sector. Business Research Unit (BRU/UNIDE), Lisbon, Portugal. Cogent Business \& Management, 4: 1360031. [Online] Available from

https://doi.org/10.1080/23311975.2017.1360031 [Accessed 19 April. 2018].

Prateek M, Nitin S and Anoop K, G. (2017) an empirical approach to consumer buying behavior in Indian automobile sector. Industrail and commercial training. Vol. 48 No.3, Pp.156-162. Emerald Group Publishing Limited, ISSN 0019-7858.

[Online] DOI 10.1108/ICT-09-2015-0061 Available from https://www.emeraldinsight.com [Accessed 19 April. 2018].

Shiffman, L. G. \& Kanuk, L.L. (2015) Consumer Behavior (15th Global Edition). New Jersey: Pearson Education. Prentice Hall.

Siphiwe, P, M. (2014) Contribution of CRM Strategies in Enhancing Customer Loyalty. Journal of Marketing Development and Competitiveness vol.8 (2)2014. [Online] Available at

http://www.na businesspress.com/JMDC/MandinaSP_Web8_2_.pdf [Accessed 19 April. 2018].

Thai Automotive industry association. (2017). Thailand Automotive Statistics.

Wikipedia. (2018). Economy of Thailand [online] Available at

https://en.wikipedia.org/wiki/Economy_of_Thailand\#cite_note-http-26 [Accessed 19 April. 2018]. 